\title{
EL TURISMO RURAL COMO ALTERNATIVA PARA EL DESARROLLO EN EL NORTE DE LA PROVINCIA DE CÓRDOBA
}

\author{
Ferrer, G. ${ }^{1}$; Barrientos, M. ${ }^{1}$; SAal, $G .{ }^{1} \&$ Mir, A. B. ${ }^{2}$
}

\begin{abstract}
RESUMEN
El Turismo rural constituye para los productores de tipo familiar una estrategia alternativa de desarrollo territorial orientada a la diversificación de actividades sustentables en el territorio. En el Norte de la provincia de Córdoba se llevan a cabo tres experiencias de este tipo promovidas por organismos estatales. Debido a que el turismo es una actividad que implica numerosas dimensiones de análisis este trabajo desarrolla un marco conceptual específico basado en la teoría de sistema. La pregunta que orienta el estudio de caso se refiere a establecer las dificultades que limitan estos procesos. Se concluye que las iniciativas se encuentran en una etapa inicial que concentra el esfuerzo en consolidar internamente al grupo que la va a gestionar (en aspectos organizativos y formativos), preparar los servicios que serán ofrecidos a la hipotética demanda y generar medios adecuados de difusión para atraer a los turistas. La simultaneidad de estas actividades genera una importante tensión que el grupo debe administrar.

Palabras clave: Turismo rural; desarrollo territorial; cambio rural; extensión universitaria.
\end{abstract}

\section{SUMMARY}

\section{Rural tourism as an alternative for development in the North of the Province of Córdoba. \\ To family farmers, rural tourism is an alternative for local-development, aiming at diversif- ying sus-tainable activities in the territory. In Northern Córdoba (Argentina) three experien- ces of this kind are carried out by peasants with the support of governmental organisms. Due to tourism is an activity that calls for the conisderation of different analytical dimensions, this paper draws upon a conceptual framework based on systems theory. To identify and discuss}

1.- Departamento de Desarrollo Rural, Facultad de Ciencias Agropecuarias (UNC).

Ing. Agr. Félix Aldo Marrone 746. Ciudad Universitaria. CC 509. (5000) Córdoba. Tel.: (0351) 4334103.

Email: guillermoferre@gmail.com

2.- Maestría en Políticas y Gestión del Desarrollo Local. CEA - UNC.

Manuscrito recibido el 12 de noviembre de 2014 y aceptado para su publicación el 23 de diciembre de 2014. 
the main constraints faced by rural tourism is the main research question followed in this case study. We conclude that these experiences are still at an early development stage where the main efforts are addressed to (a) foster the consolidation of the group who is running the initiatives (i.e., aspects related to organization and specific training); (b) set up and adjust the kind of services that will be offered to tourists; and (c) generate suitable diffusion strategies aiming at interesting tourist in the kind of activities they will offer. The management group has to handle all these issues simultaneously, which is causing significant tensions among them. Key words: Rural tourism; Local development; Rural change; Rural extension.

\section{INTRODUCCIÓN}

Este trabajo analiza en forma comparativa el proceso organizativo de tres experiencias de turismo rural apoyadas por el Estado Nacional en el Norte de la provincia de Córdoba. El objetivo es evaluar, desde un enfoque sistémico-relacional, los recursos que los grupos involucrados efectivamente movilizan en un marco territorial e histórico y los obstáculos que enfrentan en el desarrollo de sus propuestas.

El turismo rural constituye una de las nuevas actividades que proponen las instituciones estatales vinculadas al desarrollo rural en la Argentina. Para los productores agropecuarios, esta actividad se erige como una alternativa económica, complemento de su producción, que permite el uso de la capacidad instalada ociosa de los establecimientos, así como también la inclusión de la mano de obra familiar no ocupada en la producción tradicional, principalmente la de mujeres y jóvenes.

Dado el mercado en expansión que tiene el turismo rural, los expertos en el tema indican que quienes desarrollan esta actividad deben aprovechar la "tendencia contraurbana" de los últimos años que evidencia una revalorización, por parte de los habitantes de las grandes ciudades, de los espacios rurales como destino turístico (11).

Los espacios rurales comenzaron a ser revisitados conceptualmente, se los revalorizó; se los presentó como un repositorio de valores que la sociedad industrial olvidó o destruyó. Lo natural, lo auténtico, lo puro o lo personal serían algunos factores que sólo podrían hallarse en dichos espacios (11).

Por otro lado, el proceso de concentración económica ocurrido en Argentina durante los años 90 llevó a una crítica situación a una gran cantidad de productores agropecuarios y la búsqueda de alternativas impulsó al turismo rural, configurándose, en algunos casos, como la única manera viable de mantener sus establecimientos. La modificación de la función productiva tradicional que incluye la incorporación de actividades no agrícolas y servicios, en muchos casos, surge debido a la necesidad de diversificación del riesgo y generación de ingresos adicionales (9). Se produce con ello un aumento de los encadenamientos de la agricultura con otros sectores y el aumento de las ocupaciones no agrícolas de los habitantes rurales, incrementando los niveles de pluriactividad del sector (7). 